\title{
The Effect of Antibiotics on Mesophilic Anaerobic Digestion Process of Cattle Manure
}

\author{
Izabela Koniuszewska ${ }^{1}$, Monika Harnisz ${ }^{1} \mathbb{D}$, Ewa Korzeniewska ${ }^{1, *(\mathbb{D},}$, Małgorzata Czatzkowska ${ }^{1}$, \\ Jan Paweł Jastrzębski ${ }^{2} \mathbb{D}$, Lukasz Paukszto ${ }^{2} \mathbb{D}$, Sylwia Bajkacz ${ }^{3,4}$, Ewa Felis ${ }^{3,5}$ and Paulina Rusanowska ${ }^{6}$
}

1 Department of Water Protection Engineering and Environmental Microbiology, Faculty of Geoengineering, University of Warmia and Mazury in Olsztyn, Prawocheńskiego 1 Str., 10-720 Olsztyn, Poland; izabela.koniuszewska@uwm.edu.pl (I.K.); monika.harnisz@uwm.edu.pl (M.H.); malgorzata.czatzkowska@uwm.edu.pl (M.C.)

2 Department of Physiology, Genetics and Plant Biotechnology, Faculty of Biology and Biotechnology, University of Warmia and Mazury in Olsztyn, Oczapowskiego 1A Str., 10-957 Olsztyn, Poland; jan.jastrzebski@uwm.edu.pl (J.P.J.); pauk24@gmail.com (Ł.P.)

3 Department of Inorganic, Analytical Chemistry and Electrochemistry, Faculty of Chemistry, Silesian University of Technology, Krzywoustego 6 Str., 44-100 Gliwice, Poland; Sylwia.Bajkacz@polsl.pl (S.B.); ewa.felis@polsl.pl (E.F.)

4 Environmental Biotechnology Department, Faculty of Energy and Environmental Engineering, Silesian University of Technology, Akademicka 2 Str., 44-100 Gliwice, Poland

5 The Biotechnology Centre, Silesian University of Technology, Krzywoustego 8 Str., 44-100 Gliwice, Poland

6 Department of Environmental Engineering, Faculty of Geoengineering, University of Warmia and Mazury in Olsztyn, Warszawska 117 Str., 10-950 Olsztyn, Poland; paulina.jaranowska@uwm.edu.pl

updates

Citation: Koniuszewska, I.; Harnisz, M.; Korzeniewska, E.; Czatzkowska, M.; Jastrzębski, J.P.; Paukszto, Ł.; Bajkacz, S.; Felis, E.; Rusanowska, P. The Effect of Antibiotics on Mesophilic Anaerobic Digestion Process of Cattle Manure. Energies 2021, 14, 1125. https://doi.org/ $10.3390 /$ en14041125

Academic Editor: Elia Judith Martínez Torres

Received: 26 January 2021

Accepted: 12 February 2021

Published: 20 February 2021

Publisher's Note: MDPI stays neutral with regard to jurisdictional claims in published maps and institutional affiliations.

Copyright: (c) 2021 by the authors. Licensee MDPI, Basel, Switzerland. This article is an open access article distributed under the terms and conditions of the Creative Commons Attribution (CC BY) license (https:/ / creativecommons.org/licenses/by/ $4.0 /)$.
* Correspondence: ewa.korzeniewska@uwm.edu.pl; Tel.: +48-89-523-47-50

\begin{abstract}
This study explored the effect of eight antimicrobials on the efficiency of biogas production in the anaerobic digestion (AD) process of cattle manure. The microbiome involved in AD, presence and number of genes mcrA, MSC and MST specific for Archaea, and antibiotic resistance genes (ARGs) concentration in digestate (D) were examined. Supplementation of antibiotics to substrate significantly lowered biogas production. Amoxicillin caused a $75 \%$ decrease in $\mathrm{CH}_{4}$ production in comparison with the control samples. Enrofloxacin, tetracycline, oxytetracycline, and chlortetracycline reduced the amount of biogas produced by $36,39,45$ and $53 \%$, respectively. High-throughput sequencing of $16 \mathrm{~S} r \mathrm{RNA}$ results revealed that bacteria dominated the Archaea microorganisms in all samples. Moreover, antibiotics led to a decrease in the abundance of the genes mcrA, MSC, MST, and induced an increase in the number of tetracyclines resistance genes. Antibiotics decreased the efficiency of the $\mathrm{AD}$ process and lowered the quantity of $\mathrm{CH}_{4}$ obtained, while stimulating an increase in the number of ARGs in ${ }_{D}$. This work reveals how antimicrobials affect the cattle manure AD process and changes in microbial biodiversity, number of functional genes and ARGs in the digestate due to drugs exposure. It also, provides useful, practical information about the AD process.
\end{abstract}

Keywords: mesophilic anaerobic digestion; biogas production; microbiome biodiversity; antibiotic resistance genes; Illumina MiSeq Sequencing

\section{Introduction}

Anaerobic digestion (AD), which is methane fermentation, applied to the processing of organic waste (e.g., cattle manure $(\mathrm{CM})$ ), is a promising production technology generating biogas, the main component which is methane $\left(\mathrm{CH}_{4}\right)$ [1]. Cattle manure can be disposed of and recycled through the $\mathrm{AD}$ process. However, cattle manure and digestate obtained after $\mathrm{AD}$ processing can contain veterinary antibiotics (VAs) and antibiotic transformation products that have not been completely metabolised by animals [2]. Such antibiotics, such as amoxicillin or tetracycline, are metabolised in just $10-20 \%$ of the total amount, while others (e.g., sulfamethoxazole) can be metabolised up to 85\% [3]. Ahmad et al. [4] 
reported that the total volume of antibiotics consumed globally was about $2 \times 10^{8} \mathrm{~kg}$ a year, of which several thousand $\mathrm{kg}$ of VAs are released back into the environment with animal excreta.

Antimicrobial presence in substrates undergoing AD can inhibit the biogas production process and biogas yield as well as the percentage of $\mathrm{CH}_{4}$ in biogas produced during methane fermentation [5]. Methanogenic microorganisms belonging to the domain of Archaea and participating in the AD process are of key importance for biogas production and high $\mathrm{CH}_{4}$ yield. Methanogens are particularly sensitive to antimicrobials, whose presence in substrate (cattle manure) used in AD can slow down the rate of their growth and decrease their metabolic activity [6]. The risk of the occurrence of drug resistance (DR) and increasing number of antibiotic resistance genes (ARGs) in digestate from cattle manure, an AD by-product, due to the widespread use of antibiotics in veterinary medicine and agriculture, is a significant problem [7]. There is also a thread of the emergence of selection pressure and diffusion of resistant strains of microorganisms as well as their MGEs (mobile genetic elements) in digestate [6].

Over the past decades, the global consumption of antibiotics has been growing constantly. Drugs that belong to the classes of beta-lactams, tetracyclines, sulfonamides, fluoroquinolones and nitroimidazole derivatives are the most popular pharmaceuticals in veterinary medicine [8]. In this research, the aforementioned antibiotics were tested as potential inhibitors of the AD process.

To the best of our knowledge, few researchers have investigated in one experiment the effect of antimicrobials belonging to so many classes of antibiotics on biogas production, biodiversity of microbial consortia occurring in digestate from cattle manure after mesophilic anaerobic digestion process as well as the presence of ARGs, simultaneously. Moreover, only a few authors described the dependence between AD in the presence of antibiotics and the spread of drug resistance. So far, few authors have studied the influence of metronidazole, which directly affects anaerobic microorganisms, on the AD process. Moreover, there is some inconsistency in the literature regarding the effects of antibiotics on the AD process. While some authors report a reduction in $\mathrm{CH}_{4}$ production at concentrations such as $3.1 \mathrm{mg} \mathrm{L}^{-1}$ of the drug [9], other authors have shown no inhibition of $\mathrm{AD}$ even at drug concentrations of 125 to $250 \mathrm{mg} \mathrm{L}^{-1}[10,11]$. Hence, there is a need to conduct further experiments, using high doses of antibiotics and metagenomics methods, to determine the changes that occur at the microbiological level and the changes induced by antibiotics in the methanogenic community. Numerous authors [12-14] suggest that it is necessary to investigate the source, fate, and risk of such pollutants, such as antibiotics, and to control them in the AD process, which they can affect directly. Therefore, the main aim of this study was to assess the effect of selected antimicrobial drugs with high doses on (i) the efficiency of AD and biogas production, (ii) occurrence and number of mcrA, MSC, MST genes which are indicators of the presence of methanogenic microorganisms, (iii) the microbiome involved in the methane fermentation processes, and (iv) the presence and number of ARGs. In addition, degradation of antibiotics during biomethanisation was studied. The research provides the basis for understanding the impact of the selected antibiotics on bacterial communities and populations of methanogenic microorganisms that participate in biomethanisation. The article also contains some information useful to help control the AD process.

\section{Materials and Methods}

\subsection{Anaerobic Digestion}

The CM was used as substrate, while the anaerobic sludge from the laboratory methane fermentation reactor was used as the inoculum in AD (Table S1). Antibiotics belonging to beta-lactams (AMO_-amoxicillin, AMP — ampicillin), tetracyclines (OXYoxytetracycline, TET - tetracycline, CHLOR - chlortetracycline), fluoroquinolones (ENRenrofloxacin), sulfamethoxazole (SMX) and nitroimidazole derivatives (MET-metronidazole) have been selected for the study and concentrations of each are present in Table S2. 
Beta-lactams and tetracyclines were chosen because of the frequency of use in agriculture and veterinary medicine, while fluoroquinolones and sulfamethoxazole were included in the study because they may affect the growth and activity of microorganisms belonging to the Archaea domain. Metronidazole, in turn, inhibits the growth of anaerobic bacteria. The doses of antibiotics were selected based on the data published in the literature $[10,15,16]$ and on the preliminary studies that were conducted to obtain a microbiome response to drugs (unpublished data). This stage of research was conducted in order to select antibiotics that reduce the efficiency of the AD process. Methane fermentation was carried out in nine bioreactors, in eight of which a substrate enriched with one of the selected antibiotics was added. Substrate without antibiotic supplementation was the control (SA-substrate without antibiotic). The whole experiment was loaded in two replicates of each modification of bioreactor feed. The cattle manure retention time in the bioreactors was 39 days. The details related to AD conditions and biogas yield were added to Supplementary Materials (Section S1).

\subsection{Analyses of Antibiotic Concentration}

Details about sample preparation, analysis of antibiotic concentration and methods used for measuring the concentration of antibiotics in samples have been described in our previous, methodological study [17] and briefly in Supplementary Materials (Section S2).

\subsection{Genomic DNA ( $g D N A$ ) Isolation and Quantitative Analysis by $q P C R$}

Genes specific for Archaea (MSC, MST, mcrA), genes encoding resistance to beta-lactams $\left(b l a_{\mathrm{TEM}}, b l a_{\mathrm{OXA}}, b l a_{\mathrm{SHV}}, c f x \mathrm{~A}\right)$, tetracyclines $(\operatorname{tet} \mathrm{A}$, tet $\mathrm{M}, \operatorname{tet} \mathrm{Q})$, macrolide, lincosamide and streptogramin (MLS) antibiotics (erm $\mathrm{F}, \operatorname{lin} \mathrm{A}$, mef $\mathrm{A})$, sulfonamides (sul1), fluoroquinolones $\left(a a c\left(6^{\prime}\right)-I b-c r\right.$ and $\left.q e p \mathrm{~A}\right)$ and the integrase gene of class 1 and 2 (intI1 and intI2) were determined in qPCR reactions (details and conditions presented in Supplementary Materials in Section S3 and in Table S3). To study target genes, three replicate samples of cattle manure digestate were collected after the mesophilic anaerobic digestion process, then gDNA was isolated from each sample and its quantity and quality was measured, after which gDNA samples were pooled and a standardised sample prepared. Absolute abundances (AAs) of each analysed gene were presented as an average of all obtained abundance estimates and presented per gram of analysed digestate from cattle manure $\left(\mathrm{g}_{\mathrm{D}}^{-1}\right)$. The relative abundances (RAs) of the ARGs were calculated as copy number of ARGs/copy number of 16S rRNA gene.

\subsection{Illumina MiSeq Sequencing}

To identify the microbiome the high-throughput sequencing of the hypervariable region V3-V4 of 16S gene was performed with an Illumina MiSeq instrument (Seoul, Korea). Primer pairs targeting Bacteria and Archaea were selected according to Klindworth et al. [18]. The details have been described in Supplementary Materials (Section S3.3).

\subsection{Statistical Analyses}

Data were analysed using Statistica 13.1 software (https:/ / www.statsoft.pl/statistica $13 /$, accessed on 20 October 2020). Tests and diagrams use for analysis have been described in Supplementary Materials (Section S4).

\section{Results}

Antibiotics present in cattle manure subjected to the AD process may inhibit its efficiency by directly affecting bacteria and methanogens. The microorganisms involved in this process have different metabolic demands, and there is a strict dependence among them. Drugs present in substrates subjected to AD can inhibit DNA replication, RNA transcription, SOS responses, or the production of ATP in microbial organisms [19]. Pharmaceuticals can also interfere with cell division, protein translation, and cell wall synthesis or nucleotide biosynthesis [20]. Wang et al. [21] report that CHLOR in the AD process can completely 
inhibit acetoclastic methanogenic Archaea. Antibiotics, such as SMX and TET, prevent bacterial growth by binding irreversibly to the $50 \mathrm{~S}$ and $30 \mathrm{~S}$ subunits of the bacterial ribosome, respectively [22]. Sulfonamides act as competitive inhibitors of the dihydropteroate synthase enzyme that catalyses the conversion of para-aminobenzoate (PABA) to dihydropteroate (AHHMD), a precursor of folate synthesis. Tetrahydrofolic acid is involved in the synthesis of nucleic acids and, thus, prevent the growth of bacteria [23]. Sulfamethoxazole in the stage of acidogenesis and acetogenesis can destroy cell membranes, thereby improving solubilization, but at the same time increasing the production of VFAs (volatile fatty acids), the accumulation of which may also lead to lower biogas yield or inhibition of the process [24]. In AD, most of the hydrolysis and acidification processes depend on the metabolism of the bacteria, which affects its stability. Bauer et al. [25] observed that increasing the concentration of antibiotics in the process of $\mathrm{AD}$ may reduce microbial biodiversity. Amoxicillin had the most significant influence on $\mathrm{AD}$ of $\mathrm{CM}$. The $\mathrm{CH}_{4}$ production from the reactor with amoxicillin was $75 \%$ lower than from the SA and the presence of VFAs were noted (Table 1, Figure S1). The rate of biogas production was notably lower in the reactor with amoxicillin than in the other investigated reactors (Figure S1).

Table 1. The results of methane fermentation of cattle manure in the bioreactors with antibiotics supplementation and substrate without antibiotic (SA).

\begin{tabular}{|c|c|c|c|c|c|c|c|c|c|c|c|}
\hline \multirow[t]{2}{*}{ Antibiotic } & \multirow[t]{2}{*}{$\begin{array}{c}\mathrm{CH}_{4} \\
\text { Production } \\
\left(\mathrm{L} \mathrm{kg}^{-1}\right. \\
\mathrm{VS})\end{array}$} & \multirow[t]{2}{*}{$\begin{array}{c}\mathrm{CH}_{4} \\
\text { Content } \\
\text { in Biogas } \\
(\%)\end{array}$} & \multicolumn{9}{|c|}{$\begin{array}{c}\text { VFAs Concentration } \\
\left(\mathrm{g} \mathrm{L} \mathrm{L}^{-1}\right)\end{array}$} \\
\hline & & & $\begin{array}{l}\text { Acetic } \\
\text { acid }\end{array}$ & $\begin{array}{l}\text { Propionic } \\
\text { acid }\end{array}$ & $\begin{array}{c}\text { Iso-butyric } \\
\text { acid }\end{array}$ & $\begin{array}{c}\text { Butyric } \\
\text { acid }\end{array}$ & $\begin{array}{l}\text { Iso-valeric } \\
\text { acid }\end{array}$ & $\begin{array}{c}\text { Valeric } \\
\text { acid }\end{array}$ & $\begin{array}{c}\text { Iso-caproic } \\
\text { acid }\end{array}$ & $\begin{array}{c}\text { Caproic } \\
\text { acid }\end{array}$ & $\begin{array}{c}\text { Heptanoic } \\
\text { acid }\end{array}$ \\
\hline MET & $143.4 \pm 44.0$ & $70.7 \pm 4.7$ & 0.00 & 0.00 & 0.00 & 0.00 & 0.00 & 0.00 & 0.00 & 0.00 & 0.00 \\
\hline AMO & $51.2 \pm 27.0$ & $61.5 \pm 11.4$ & $16.11 \pm 2.09$ & $5.96 \pm 0.99$ & $6.46 \pm 1.12$ & $4.56 \pm 0.89$ & $7.75 \pm 1.45$ & $2.93 \pm 0.43$ & $4.34 \pm 0.85$ & $0.89 \pm 0.29$ & $0.23 \pm 0.11$ \\
\hline AMP & $138.6 \pm 19.6$ & $69.1 \pm 3.3$ & 0.00 & 0.00 & 0.00 & 0.00 & 0.00 & 0.00 & 0.00 & 0.00 & 0.00 \\
\hline ENR & $72.5 \pm 14.7$ & $72.9 \pm 12.5$ & 0.00 & 0.00 & 0.00 & 0.00 & 0.00 & 0.00 & 0.00 & 0.00 & 0.00 \\
\hline SMX & $183.1 \pm 54.1$ & $71.4 \pm 3.9$ & 0.00 & 0.00 & 0.00 & 0.00 & 0.00 & 0.00 & 0.00 & 0.00 & 0.00 \\
\hline OXY & $91.5 \pm 33.1$ & $68.2 \pm 5.4$ & 0.00 & 0.00 & 0.00 & 0.00 & 0.00 & 0.00 & 0.00 & 0.00 & 0.00 \\
\hline CHLOR & $107.0 \pm 54.9$ & $68.7 \pm 4.1$ & 0.00 & 0.00 & 0.00 & 0.00 & 0.00 & 0.00 & 0.00 & 0.00 & 0.00 \\
\hline TET & $79.2 \pm 23.7$ & $69.4 \pm 3.8$ & $6.35 \pm 2.54$ & $0.43 \pm 0.09$ & $0.48 \pm 0.14$ & $0.26 \pm 0.07$ & $2.35 \pm 1.06$ & $0.68 \pm 0.22$ & $0.35 \pm 0.08$ & $0.12 \pm 0.04$ & $0.03 \pm 0.01$ \\
\hline SA & $201.2 \pm 9.7$ & $70.8 \pm 3.5$ & $0.26 \pm 0.10$ & $0.03 \pm 0.03$ & $0.03 \pm 0.03$ & 0.00 & $0.04 \pm 0.03$ & $0.02 \pm 0.02$ & $0.01 \pm 0.01$ & $0.01 \pm 0.01$ & $0.04 \pm 0.02$ \\
\hline
\end{tabular}

$\mathrm{CH}_{4}$-methane, VS—volatile solids, VFAs—volatile fatty acids, MET—metronidazole, AMO—amoxicillin, AMP—ampicillin, ENR— enrofloxacin, SMX — sulfamethoxazole, OXY—oxytetracycline, CHLOR—chlortetracycline, TET—tetracycline, SA—substrate without antibiotic (control), \pm indicates standard deviation.

The highest concentration was determined for acetic acid $\left(16.11 \pm 2.09 \mathrm{~g} \mathrm{~L}^{-1}\right)$. However, concentrations of other acids were also higher than in the SA. The higher concentrations of VFAs increased also slightly the FOS/TAC ratio (the ratio of volatile organic acids to alkaline buffer capacity and measure the risk of acidification of a biogas plant) (Table S4). Sun et al. [26] investigated the combined effect of amoxicillin, aureomycin, sulfadimethoxine, and florfenicol on AD of piggery wastewater and observed that AMO was the second most strongly inhibiting antibiotic. Nuengjamnong et al. [27], who measured only the influence of AMO, showed that the presence of AMO inhibited the $\mathrm{CH}_{4}$ production. Lallai et al. [10] noted a decrease in $\mathrm{CH}_{4}$ production from pig slurry enriched with amoxicillin trihydrate at a dose of 0.6 and $0.12 \mathrm{mg} \mathrm{L}^{-1}$. The significantly lower $\mathrm{CH}_{4}$ production was noted in reactors with AMP, OXY, ENRO, CHLOR, and TET. Similarly, Bauer et al. [25] noted that the concentration of ENRO and CHLOR of $0.2 \mathrm{~g} \mathrm{~L}^{-1}$ inhibited $\mathrm{CH}_{4}$ yields from pig slurry. However, in the present study higher concentrations of VFAs were observed (except the bioreactor with AMO addition) only in the bioreactor with TET. This antibiotic increased mainly acetic acid and iso-valeric acid concentration in the digestate. In the reactor with TET also the lowest rate of biogas production was observed (except the bioreactor with AMO addition) (Figure S1). The indicators of AD (for example FOS/TAC ratio or $\mathrm{pH}$ ) were not changed in the bioreactors with AMO, OXY, ENRO, CHLOR, and TET. Min et al. [28] showed that a concentration from 0.1 to $0.5 \mathrm{~g} \mathrm{~L}^{-1}$ of OXY only slightly inhibited AD, although a concentration of OXY in the range of $1-2 \mathrm{~g} \mathrm{~L}^{-1}$ decreased the biogas production from 199.6 to $41.9 \mathrm{~L} \mathrm{~kg}^{-1}$ vs. (volatile solids), respectively. These observations were confirmed in the present study, where the OXY concentration was 
over $1 \mathrm{~g} \mathrm{~L}^{-1}$, and the inhibition of $\mathrm{CH}_{4}$ production was observed. Massé et al. [29] reported that TET reduced $\mathrm{CH}_{4}$ production by $25 \%$ when it was included at the maximum allowable level in the diet of pigs. Arikan et al. [9] reported that cumulative biogas production was $27 \%$ lower from anaerobic digesters containing cattle manure treated with $0.2 \mathrm{~g} \mathrm{~kg}^{-1}$ per day OXY for 5 days compared to manure from untreated calves. Wang et al. [15] showed that when the concentration of an antibiotic reached $0.1 \mathrm{~g} \mathrm{~L}^{-1}$, the rate at which biogas was produced in AD decreased drastically. Having added antibiotics to substrates, these authors noted the accumulation of VFAs in bioreactors, which led to the inhibition of $\mathrm{CH}_{4}$.

Based on the results of this and other studies it was concluded that drugs significantly reduce the amount of biogas produced. However, the impact of antimicrobials depends on their class, dosage, and the method by which the residues are transferred to bioreactors (i.e., direct supplementation to bioreactor or as a content of manure) [30].

\subsection{Fate of Antibiotics During AD}

The AMO was not detectable in any fraction of the CM after the AD process-neither in the liquid fraction nor in the solid phase of the samples. Ampicillin was detected only in the liquid phase of the samples, while MET was determined only in the solid phase of the samples (the concentration did not exceed $0.02 \mu \mathrm{g} \mathrm{g}_{\mathrm{D}}{ }^{-1}$ ). Other compounds were detectable in post-treatment samples in both the liquid and solid phases. The results allowed us to estimate the values of drug degradation coefficient $\left(K_{d}\right)$ parameters (according to Equation (1) Section S2.2 in Supplementary Materials), which are known to be a measure of sorption affinity on solid (suspended) particles of a sample. The determined sorption parameters of the tested compounds (Table S5) allowed us to estimate the total compounds concentration in the bioreactor according to Equation (2) (Section S2.2 in Supplementary Materials), (Table S6), which subsequently enabled the calculation of total removal efficiency (Equation (3) (section S2.2 in Supplementary Materials) (Table S7)).

The calculated values of $K_{d}$ parameters indicated that none of tested antibiotics showed very strong affinity for the solid fraction of the CM (Table S7). The highest values of these coefficients were observed for TET $\left(\log K_{d}=1.6\right)$, although they indicate only moderate affinity for sorption onto the solid (suspended) fractions. Bajkacz et al. [17] observed that the antibiotics, such as tetracyclines and quinolones, were fairly stable under the conditions of anaerobic digestion. Álvarez et al. [30] observed that CHLOR and OXY showed a strong tendency to be adsorbed onto the solid fractions of manure (especially fresh one). Loke et al. [31] reported that OXY binds readily to organic molecules in manure. Kühne et al. [32] reported a TET half-life of 9 days in non-aerated pig manure at ambient temperature. Arikan [33] investigated the fate of CHLOR in calf excrements and found that the concentration of the drug decreased by $75 \%$ in a 33 day digestive period, but the concentration of the drug metabolite isochlortetracycline increased 2 fold over the same period. Both of these compounds are able to form strong complexes with divalent cations, which are abundant in pig manure, and demonstrate the capacity to be adsorbed onto proteins and organic matter [31]. However, as a result of biochemical processes occurring during the AD, organic biomass undergoes transformation into biogas and, thus, the solid fraction of the manure remaining after the process significantly changed its physico-chemical properties (including the content of organic compounds). Therefore, the values of $K_{d}$ coefficients determined in this experiment indicated much greater affinity of the tested compounds for the liquid than the solid phase. In addition, the concentrations of antibiotics used in the investigations were higher than those described by Alvarez et al. [30] and probably the adsorption of these substances could be limited by the available superficial area of the solid fraction of the inoculum and the manure, especially that the hydration of the samples was very high and exceeded 93\% (Table S8).

In the experiment, the antibiotics were degradable at varying levels, from $57 \%(\mathrm{OXY})$ to $100 \%$ (MET, AMO, AMP and SMX). However, even for substances for which the complete degradation was observed, their transformation by-products were present in the solid phase 
of the digested CM. Due to the nature of the experiments carried out, the transformation by-products were identified only tentatively, based on the comparison of data from previously published references [2,34] and taking into account collision-induced dissociation mass received in different modes of operation of the mass spectrometer such as: precursor ion, product ion(s) and neutral loss. Some authors $[30,35]$ stated that mainly isomeric transformations at the molecular level may occur at the beginning of the AD. The formation of epimers of TET and CHLOR, that is 4-epi-tetracycline and 4-epi-chlortetracycline, respectively, are mentioned as examples of such transformations [30], but none of these by-products were observed in this study. However, in the case of other antibiotics, such as SMX, AMO, and AMP, the formation of by-products with the same molecular weight (but different retention time) was observed. These products were tentatively identified as 4-amino-N-(5-methyl-1,3-oxazol-2-yl)benzenesulfonamide or 4-amino-N-(5-methyl-1,2oxazol-3(2H)-ylidene) benzenesulfonamide, diketopiperazine amoxicillin, and diketopiperazine ampicillin. The explicit confirmation of the structures of the tentatively identified transformation by-products requires further research consisting of the comparison of the precursor and product ions as well as the retention times obtained for the tentatively identified by-products with the same parameters of the analytical standards of these substances. However, this may be a certain analytical challenge because the analytical standards of these by-products are not available commercially.

\subsection{Impact of $A D$ on Microbial Community}

The taxonomic distribution of bacterial diversity as percentages of groups at the phylum level in digestate was visualized with Circos (Figure 1). The analysed digestate mass via the profiling of the gene 16S rRNA, was found to contain 324 OTUs.

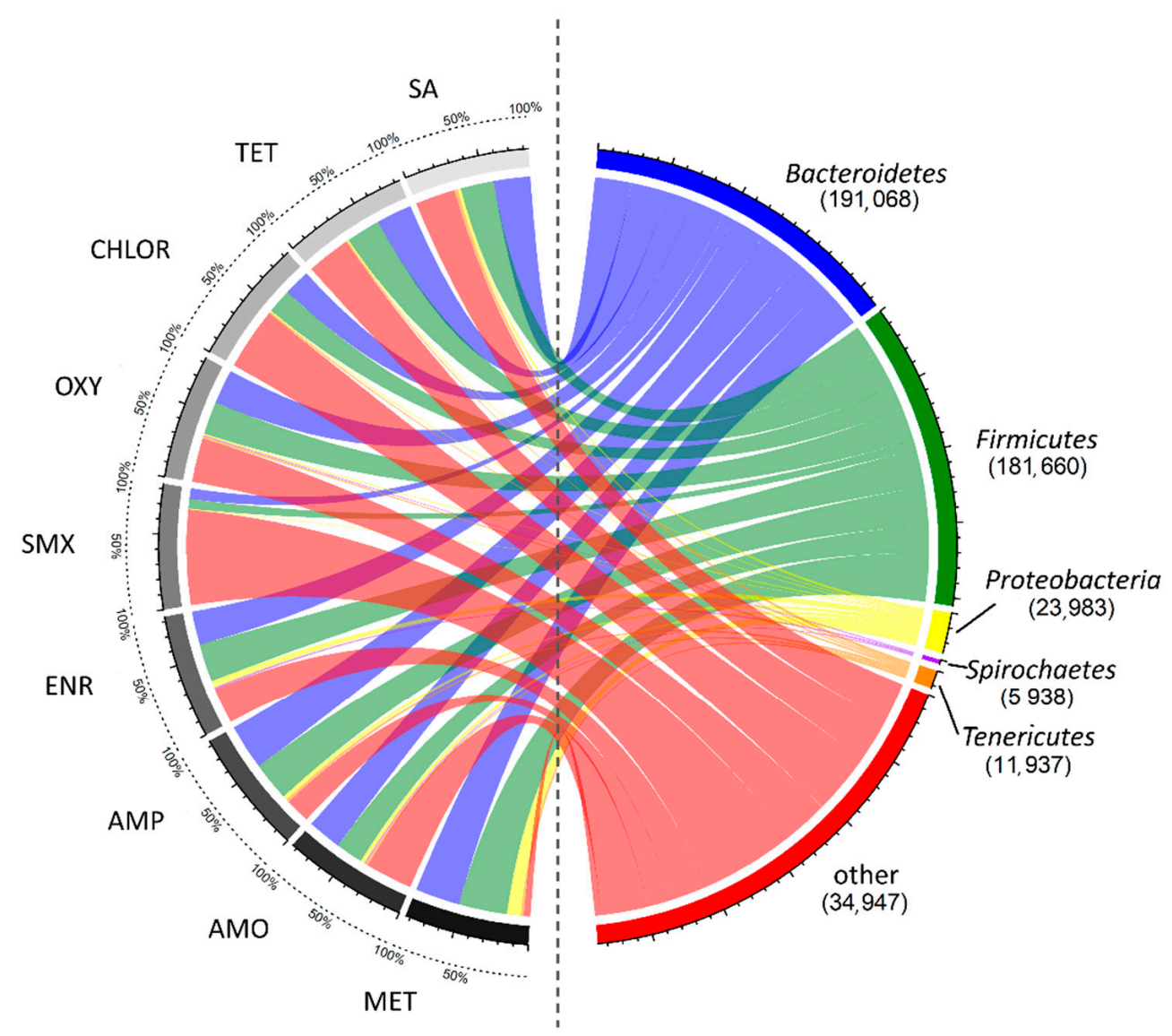

Figure 1. The taxonomic distribution of bacterial diversity as percentage values at the phylum level in digestate. Data visualised in Circos, where on the left is the percentage of microorganisms in the bioreactor and on the right is the sum of sequencing readings for a particular bioreactor. 
The high-throughput sequencing analysis revealed considerable changes in the population of microorganisms in digestate depending on the added antibiotic. Among the identified OTUs in the analysed samples of digestate, the most numerous were the microorganisms of the types Bacteroidetes and Firmicutes which can decompose VFAs, are tolerant to fluctuations of temperature, $\mathrm{pH}$ and the availability of oxygen, and are characterised by the potential capability of hydrolysis and hydrogenogenic acidogenesis [36]. As well as degrading proteins, most bacteria of the type Bacteroidetes produce lytic enzymes and acetic acid and are widespread in AD of different substrates [37]. Previous studies also showed that the Firmicutes to Bacteroidetes ratio can serve as an indicator of the stability of AD [38]. In the digestate with added MET or AMP, the Bacteroidetes type made up almost $40 \%$ of the microbial community, while TS was reduced in the digestate with MET, and $\mathrm{CH}_{4}$ yield decreased in both digestate samples. In the digestate with AMO, ENRO, OXY or TET, Bacteroidetes constituted nearly $30 \%$ of all identified microorganisms, while the yield of $\mathrm{CH}_{4}$ was found to be lower (decreased by three-fold in comparison to SA) and the TS content was decreased relative to the SA variant. The Bacteroidetes and Firmicutes types made up $22 \%$ each of the microbial community in the digestate supplemented with CHLOR. A sample of the digestate including SMX showed the most extensive changes in the microbial community relative to the SA. Numerous genera Bacteroides and Paludibacter belonging to the type Bacteroidetes were found in all bioreactors with the supplementation of antimicrobials (Figure S1). Microorganisms belonging to the Bacilli and Clostridia classes dominated among the Firmicutes type. In most of the bioreactors, numerous reads of the genera Bacillus, Rumellibacillus, Enterococcus, Turicibacter, belonging to the Bacilli class, were achieved. However, the number of reads per sample for the most of drug-supplemented bioreactors was significantly lower compared to the SA. The types Bacteroidetes and Firmicutes represented $10 \%$ each of the community of microorganisms in the digestate with SMX. It is highly probable that during the process of SMX transformation, the antibiotic degradation products [17] caused a decrease in the abundance of microorganisms, thereby leading to a fall in $\mathrm{CH}_{4}$ yield due to the insufficient amounts of substrate supplied by bacteria to methanogenic microorganisms.

Microorganisms of the type Proteobacteria represented $11.8 \%$ of the OTUs in digestate with MET, 5.99\% in digestate with ENRO and nearly 4\% in samples of digestate with AMO and AMP. Meanwhile, Proteobacteria made up slightly over $1 \%$ of the microbial community in digestates supplemented with TET drugs. Among the microorganisms belonging to the Proteobacteria type, the Alpha-, Beta- and Gammaproteobacteria classes were dominant. The predominant genus among Alphaproteobacteria belonged to the order Rhizobiales. The Oligella genus belonging to the order Burkholderiales dominated among Betaproteobacteria. Among the Gammaproteobacteria, numerous genera of Pseudomonas belonging to the order Pseudomonadales were noted. Proteobacteria play a very important role in AD by consuming glucose, acetate and propionate (VFAs), which-if accumulated in large amounts - may cause a decrease in $\mathrm{pH}$, which most often leads to some disorder or inhibition of the process [6,39]. Other important types of microorganisms included Spirochaetes (more than 1\% in samples with AMO, ENRO or OXY), genera Treponema and Tenericutes (over 2\% in digestate with MET, AMO, AMP and 1\% in sample with TET), genus Acholeplasma (over 1\% in samples with MET, AMO, AMP, ENR, OXY, CHLOR and TET). Sequencing revealed a few readings for the Archaea domain. The genera Mathanosarcina and Methanosaeta were identified most frequently (over $1 \%$ sequentially in samples with MET, AMP, SMX, OXY, CHLOR, TET and in samples with MET, AMP, ENRO, OXY, CHLOR, TET) which is consistent with the GPCR analysis conducted in this study, targeting the MSC and MST genes, specific for the Methanosarcinaceae and Methanosaetaceae families (Figure 1 and Figure S2).

Summarising, the microbial community was mainly represented by Bacteroidetes, Firmicutes, Proteobacteria, Spirochaetes and Tenericutes, which is consistent with the results of experiments conducted by other researchers $[6,40,41]$. The identified microorganisms are characterised by hydrolytic capability, and products of hydrolysis serve as substrate 
to microorganisms involved in acidogenesis in order to produce VFAs. Bacteroidetes, Firmicutes and Proteobacteria can decompose VFAs and use them as a source of carbon for their metabolic activity. In contrast to SA, most of the analysed digestate samples (except the one with AMO and TET) were not detected to contain VFAs. It is highly probable that microorganisms present in digestate, by using the available substrates as a source of carbon [42,43], diminished the supply of VFAs to acetogenic microorganisms, which in turn, lacking sufficient amounts of substrate, decreased the rate of their production as the substrate for methanogenic microorganisms. This led to the disturbance of the methanogenesis pathway and to the decrease of the efficiency in $\mathrm{CH}_{4}$ production in all samples of digestate supplemented with antibiotics. The profiling of the 16S rRNA fragment suggests that the identified Bacteroidetes and Firmicutes can play a significant role in degradation and removal of TS. Based on the research results presented herein, it can be concluded that the types Bacteroidetes and Firmicutes, in the presence of antibiotics, did not supply adequate quantities of substrates for biogas producing methanogenic microorganisms. Delbès et al. [44] also emphasise that the community of microorganisms engaged in $\mathrm{AD}$ can be affected by changes in the environmental conditions, which can lead to reducing the productivity of a reactor or to processing errors, such as excessively lowered $\mathrm{pH}$ causing the acidification of the environment and decreased $\mathrm{CH}_{4}$ yield, a consequence of which, with varying degrees of intensify, was observed in all the digestate samples analysed in this study.

\subsection{Impact of AD on the Prevalence of mcrA, MSC and MST Genes \\ 3.3.1. mcrA Gene}

The absolute abundances of $m c r$ A gene copies (in the order of $10^{1}$ to $10^{8}$ copies $\mathrm{g}_{\mathrm{D}}{ }^{-1}$ ) can reflect the level of methanogens participating in AD (Table 2) [6,45].

Relative abundances (RAs) of the number of genes are shown in Supplementary Materials (Table S9). In this research, compared to the SA, statistically significant (ANOVA KruskalWallis; $p<0.05 ; N=6$ ) differences in the number of copies of the gene mcr A among samples of digestate with added antibiotics were observed (Figure S3). An increase in the number of copies of the gene $m c r A$ in the order of $10^{6}$ copies $\mathrm{g}_{\mathrm{D}}{ }^{-1}$ was observed in the presence of OXY, CHLOR and TET. The mcrA gene encoding the subunit of $\alpha$ reductase of methylcoenzyme $\mathrm{M}$, which catalyses the final stage of methanogenesis, is described as a potential biomarker of the $\mathrm{CH}_{4}$ yield during methanogenesis [46]. A decrease in the number of copies of the gene mcrA in comparison with SA was observed in the digestate samples with MET, AMO, AMP and SMX. An increase in the number of copies of the gene mcrA in digestate samples supplemented with tetracycline drugs alongside a decrease in $\mathrm{CH}_{4}$ yield can indicate that these drugs exerted the selection pressure on methanogenic microorganisms throughout the experiment. As TET is a much more difficult xenobiotic compared to the substrate mixture fed to the bioreactor, it is more likely that the main mechanism for TET removal observed in this study is metabolite formation rather than biodegradation. Tetracyclines inhibited methanogenic microorganisms, but only slightly, as evidenced by a low amount of accumulated VFAs in bioreactors during the AD process [47]. In addition, due to the long-term selection pressure of tetracycline on microorganisms, they developed adaptation and resistance mechanisms, as evidenced by the high number of copies of genes characteristic of methanogens. This interpretation was also fully supported by a metagenomic analysis of the microbial community based on sequencing techniques which revealed numerous readings for the methanogenic Archaea (Figure S2). 


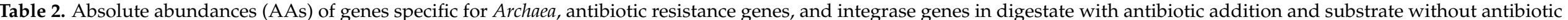
addition. AAs were calculated as copy number of an antibiotic resistance genes in $1 \mathrm{~g}$ digestate $\left(\mathrm{g}_{\mathrm{D}}{ }^{-1}\right)$.

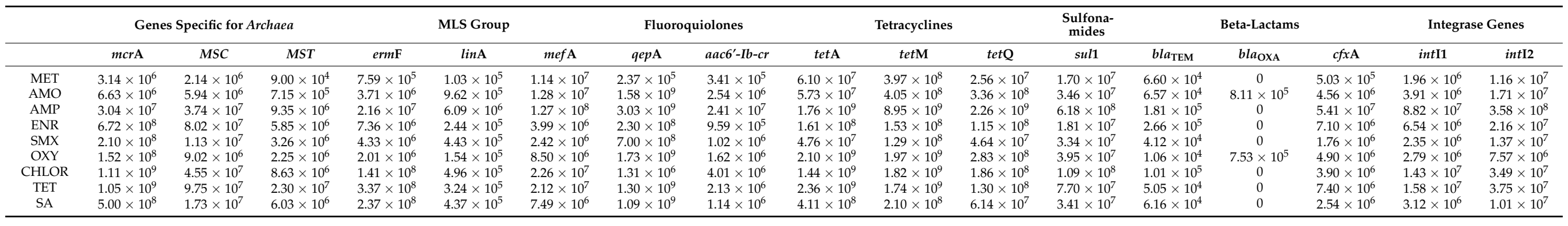


The high drug degradation coefficient $\left(K_{d}\right)$ achieved in this study suggests the presence of a small amount of tetracyclines in digestate throughout the whole experiment. Alvarez et al. [30] report that the half-time of adsorbed tetracyclines in manure is longer than in other environments. Martinez [48] and $\mathrm{Wu}$ et al. [49] also observed increased adsorption of tetracycline after the AD process, which was demonstrated to improve the stability of tetracyclines and to minimise their degradation. The results of this study suggest that microorganisms may have used the tetracycline as a source of carbon [50], and that these drugs simultaneously inhibited the expression of the gene mcrA. Consequently, the concentration of the gene mcrA was high but microorganisms were not active metabolically and produced less $\mathrm{CH}_{4}$.

\subsubsection{MST and MSC Genes}

Presence and number of genes characteristic of the two families of acetoclastic methanogens: Methanosarcinaceae (MSC) and Methanosaetaceae (MST), were examined during AD. These methanogens require higher concentrations of acetic acid, which they convert to $\mathrm{CH}_{4}$; they are characterised by a more rapid rate of substrate conversion than other families of microorganisms [51], and they constitute the majority of Archaea in fermentation chambers. In this experiment, statistically significant $(p<0.05)$ differences were determined in numbers of MSC and MST genes between digestate samples (Figure S3). High concentration of MSC and MST genes was noted in samples of digestate with AMP, OXY, CHLOR and TET (number of copies of the genes in the order of $10^{6}$ to $10^{7} \mathrm{~g}_{\mathrm{D}}{ }^{-1}$ ) (Table 2). In the other samples with antibiotics, there was a decrease in the number of copies of the genes MSC and MST in comparison with SA, possibly indicating the inhibitory effect of MET, AMO, ENR and SMX on the growth and development of the methanogenic organisms described in this paper. Bauer et al. [52] noted small numbers of the Methanosaetaceae and Methanosarcinaceae in an AD system following the application of antibiotics. Turker et al. [53] also noted reduction in the abundance of Methanosarcinaceae in AD of CM with antibiotics. The family Methanosaetaceae contains strictly anaerobic microorganisms, extremely sensitive to changes occurring in the environment during AD, especially to the addition of inhibitors like antibiotics, to low $\mathrm{pH}$ or to fluctuations in temperature [25].

\subsection{Impact of AD Process on the AAs of Analysed ARGs and Integrase Genes, and Their} Prevalence in Bioreactors

\subsection{1. tet Genes}

Statistically significant $(p<0.05)$ differences were determined in the number of copies of tet genes (in the order of $1.0 \times 10^{8} \mathrm{~g}_{\mathrm{D}}^{-1}$ ) between samples of digestate with the content of different antibiotics (Figure S4). In most digestate samples, compared to the control, there were numerous ARGs carrying resistance to tetracyclines (Table 2) which agrees with the results provided by other authors [30,49]. In this study, the concentrations of tetracycline antibiotics added to substrates most probably effected selective pressure on the number and dissemination of ARGs in digestate from CM. tet genes are widespread in $\mathrm{CM}$ and the antibiotics present in $\mathrm{AD}$ systems additionally induce the increasing resistance to these antibiotics [54,55], which explains their high abundance in digestate samples observed in this experiment. It is possible that tet genes are a stable part of the genomes of animals' physiological microbiota [56] and, therefore, are evacuated from intestines to animal manure, where DR can be spread via HGT. In this study, samples of digestate with MET or SMX were observed to contain a lower number of copies of the tetA and tetQ genes by one order in comparison to the SA.

\subsection{2. bla Genes}

The AAs of the bla genes in $1 g_{\mathrm{D}}^{-1}$ varied within the order of $10^{4}-10^{7}$ of copies of the gene (Table 2$)$. In comparison with SA, statistically significant $(p<0.05)$ differences were observed in the AAs values for the $b l a_{\mathrm{TEM}}$ gene. The number of copies of the $b l a_{\mathrm{TEM}}$ gene was higher by one order in $1 \mathrm{~g}$ of a sample of digestate with added AMP, ENR or CHLOR 
(Figure S5). In addition, an evident increase in the number of copies of the $c f x \mathrm{~A}$ gene by one order in $1 \mathrm{~g}$ of digestate in the presence of AMP was observed relative to the SA. Many authors $[57,58]$ describe the $b{ }_{1} a_{\text {TEM }}$ gene as the one most frequently present among the bla genes in environmental samples. The presence of the $b l a_{\mathrm{OxA}}$ gene was unobserved in most of the analysed digestate samples. Degradation of beta-lactam antibiotics in the AD process could have been the reason why the bla OXA gene was absent. Bacteria show resistance to beta-lactam antibiotics through the acquisition of beta-lactamase genes, responsible for the tolerance to these drugs. Beta-lactamases react on the beta-lactam ring of beta-lactams, which enable the bacteria to acquire resistance to these antibiotics. However, the instability of the beta-lactam ring in beta-lactam antibiotics can cause their rapid degradation in the environment, and therefore prevent the bacteria present in this ambient to gain drug-resistance to these antibiotics $[59,60]$.

\subsection{3. sul1 Gene}

Compared to SA (number of copies of the gene sul1 in the order of $10^{7} \mathrm{~g}_{\mathrm{D}}^{-1}$ ), statistically significant $(p>0.05)$ differences were determined between samples of digestate with the content of different antibiotics in the number of the sul1 genes (Figure S6). An increase in the number of the sul 1 gene by one order $\left(10^{8}\right.$ copies of the gene $\left.\mathrm{g}_{\mathrm{D}}{ }^{-1}\right)$ was determined in samples of digestate with AMP, TET and CHLOR (Table 2). The formation of transformation products during AD depends on the type of an antibiotic and its concentration added to the substrate in a bioreactor [61]. Complete degradation of SMX was observed in this study, although it is possible that products of the transformation of this compound may appear and remain in digestate mass. Bajkacz et al. [17] observed SMX transformation products in the cattle manure digestate in which the change occurred within the isoxazole ring. The authors noted that epimerisation of antibiotics appears to be the first step in transformation under the anaerobic conditions of the AD process. Similar results were also observed by Spielmeyer et al. [2]. It is highly probable that the supplementation of SMX to substrate caused selection pressure and increased number of ARGs to this drug. On the genetic level, DR results in the presence of ARGs in chromosomes and/or in MGEs, such as integrases, noted in high numbers of the digestate samples analysed in this research [56]. The factors mentioned above, such as selection pressure or presence of the integrase genes, are closely connected with the abundance of ARGs in the AD process, causing mutations of ARBs (antibiotic resistance bacteria) and acquisition of new features, including DR [21,62].

\subsubsection{MLS Group Genes}

The value of $\mathrm{AAs}$ of the $\operatorname{erm} \mathrm{F}$, lin $\mathrm{A}$, mef A genes ranged from $10^{5}$ to $10^{8}$ copies of the gene $g_{D}^{-1}$ (Table 2). Relative to SA statistically significant differences were noted in the number of the mefA gene between samples of digestate supplemented with antibiotics. In comparison with SA (number of copies in the order of $10^{6} \mathrm{~g}_{\mathrm{D}}^{-1}$ ), the mef A gene appeared in high numbers in digestate with MET, AMO, AMP, CHLOR and TET. In samples of the digestate with AMP, compared to SA, a rise in the number of the mef A gene by two orders was noted (Figure S7). In samples of digestate with added MET, AMO, CHLOR or TET, the mefA gene was present in quantities in the order of $10^{7}$ copies $\mathrm{g}_{\mathrm{D}}{ }^{-1}$. Small amounts of metronidazole and considerable amounts of tetracycline drugs were detected in digestate after the AD process. The antibiotics present in digestate may have induced an increase in the DR to these pharmaceutical substances. A significant role in the increase of ARGs in digestate samples may have also been played by the ongoing HGT processes. According to Bouanane-Darenfeld et al. [63] it is also possible that some genera of the methanogenic Archaea, including Methanosaeta, found in digestate samples are potential hosts of ARGs, responsible for the resistance to MLS antibiotics.

\subsubsection{Fluoroquinolones Resistance Genes}

In comparison with SA, particularly high and statistically significant (ANOVA KruskalWallis; $p<0.05 ; N=6)$ differences in the number of the qepA genes $\left(1.0 \times 10^{9}\right.$ copies of 
the gene $\mathrm{g}_{\mathrm{D}}^{-1}$ ) were determined for samples of digestate with AMO, AMP and OXY (Table 2) (Figure S8). Fluoroquinolones are compounds that adsorb strongly to organic matter present in all types of faeces [64], owing to which their degradation is much weaker than that of other antibiotics, like beta-lactams. Selvam et al. [55] noted the presence of genes carrying resistance to fluoroquinolones after 56 days of composting pig manure. Qu et al. [65], who analysed poultry droppings, noted numerous presences of genes resistant to fluoroquinolones. In this study, a decrease in the numbers of the qep $\mathrm{A}$ and aac $6^{\prime}$-Ib-cr genes was observed only in the digestate with added MET.

\subsubsection{Integrase Genes}

The value of AAs of the analysed ARGs in most of the samples of digestate with added antibiotics ranged within $10^{6}$ to $10^{8}$ copies of the gene $\mathrm{g}_{\mathrm{D}}^{-1}$ (Table 2, Figure S9). The number of genes in the SA oscillated around $10^{6}$ to $10^{7}$ copies of the gene $\mathrm{g}_{\mathrm{D}}{ }^{-1}$. The high number of copies of the genes intI1 and intI2 in samples of digestate supplemented with antibiotics and the SA sample can testify to the possibility of spreading ARGs through the HGT process. The abundance of the genes intI 1 and intI2 can therefore serve as an indicator of the HGT processes [66]. In this experiment, the concentrations of intI1 and intI2 in most samples of digestate supplemented with antibiotics increased by one order in comparison to SA samples (ANOVA Kruskal-Wallis; $p<0.05 ; N=6$ ). A similar number of copies of the tested integrase genes in an AD system may indicate the adaptation of microorganisms to the concentrations of antibiotics applied at the onset of the AD process [6]. The results obtained in this study are consistent with the ones reported by other authors. Gaze et al. [66] showed that the selection pressure exerted by antibiotics can increase the number of copies of the integrase genes. Allen et al. [57] investigated the share of sequences associated with transposition elements and plasmids in the microbiome of farm animals and recorded their higher contribution in animals treated with antibiotics than in the control group. These authors concluded that antibiotics could induce DR as well as the growth and spread of ARGs on a broad scale in the environment. However, it is HGT that remains the main mechanism for the dissemination of ARGs in the environment, which poses an immense threat to animal and human health due to DR, as well as limiting the possibilities of controlling this phenomenon [67].

\subsection{Results of Statistical Analyses}

The Spearman's correlation analysis applied to investigate ARGs, genes specific for Archaea and integrase genes in $1 \mathrm{~g}$ of digestate, showed very strong, statistically significant positive correlations between numbers of these genes $(R>0.8)$ (Figure 2).

The ermF gene highly correlated with the genes MST $(R=0.8153, p<0.05), m c r A$ and $\operatorname{MSC}(R=0.8158, p<0.05)$. High correlation also appeared between the number of sul 1 and integrase genes, with the correlation with intI1 and with intI2 reaching $R=0.8184(p<0.05)$. Previously published studies have also confirmed the positive correlation between ARG and intI1 and antibiotic concentrations in livestock and poultry faeces [68]. Moreover, Luo et al. [69] found that intI1 was associated with the spread of sul1 and sul2.

High, statistically significant correlation between genes can suggest that the microorganisms present in digestate may have been drug-resistant, and the selection pressure exerted by antibiotics caused their growth and the spread of DR during the AD process. The genes intI1 and intI2 showed statistically significant $(p<0.05)$ positive correlations with most of the analysed ARGs ( $\mathrm{R}=$ od 0.60 do 0.82 ), which suggests an important role of these genes in HGT. The results of the statistical analysis performed in this study overlap with the data reported by other researchers, who demonstrated a strong and significant correlation between ARGs and the presence of integron [70].

High, statistically significant correlations $(p<0.05)$ were determined between the type Spirochatetes and the gene bla OXA $(R=0.70)$ (Figure 3$)$, which implicates the succession of Spirochaetes, which can condition changes in ARGs present in digestate obtained from cattle manure [71]. 


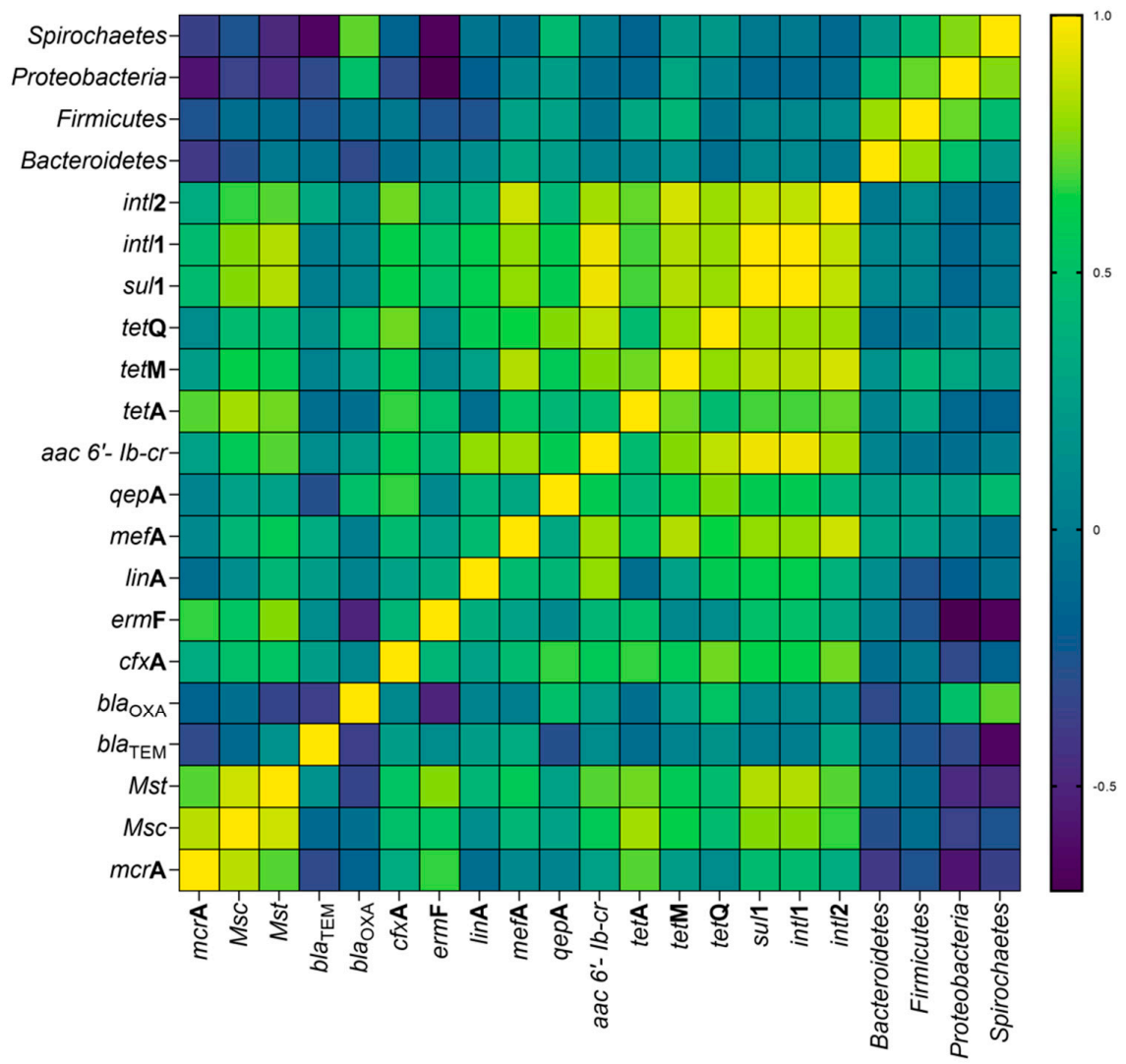

Figure 2. Spearman's rank order correlation analysis between studied genes.

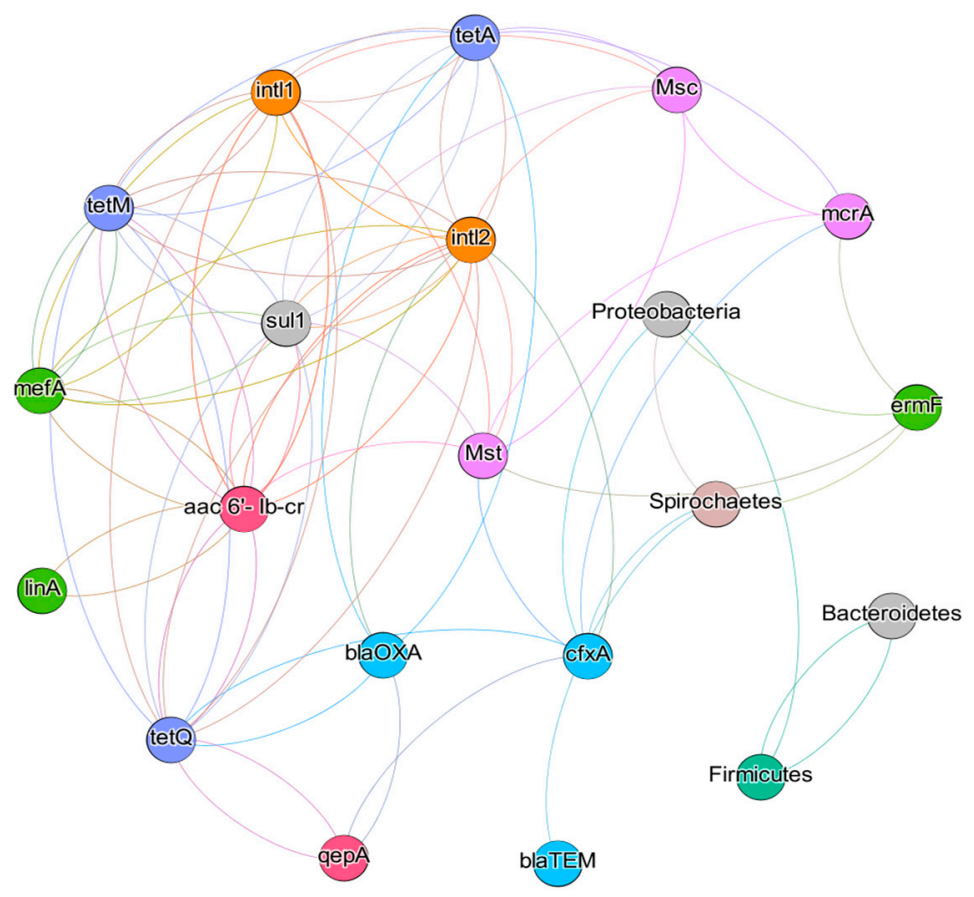

Figure 3. The network analysis showing the co-occurrence patterns between the detected ARGs and microbial taxa (type level). The nodes were coloured according to ARGs types and bacterial taxa. The connection between ARGs and bacterial taxa represents a strong (Spearman's correlation coefficient $R>0.7$ ) and significant ( $p$-value $<0.01$ ) correlation. Node size is proportional to the number of connections; edge width is proportional to Spearman's $p$-value. 
Proteobacteria and Spirochaetes demonstrated a high, statistically significant $(p<0.05)$ mutual correlation $(R=0.77)$ and correlated negatively with the gene erm $\mathrm{F}(R=-0.70)$, indicating that their hosts were different [41]. The type of bacteria Firmicutes highly correlated with the type of bacteria Bacteroidetes $(R=0.70)$ and with Proteobacteria $(R=0.72)$ (Figure 3). Consistent results of studies carried out by many researchers provide direct evidence that the spread of ARGs can be correlated with residues of antibiotics in the environment, and this information should improve the current understanding of the distribution of ARGs and their connection with the succession of microbial communities.

\subsection{Impact of Physicochemical Parameters on the Microbial Community in Bioreactors}

Zhang et al. [6] report that fluctuations of $\mathrm{pH}$ and accumulation of VFAs in bioreactors can lead to disturbances in the AD process and decrease in the efficiency of methanogenesis. In this experiment, no significant changes in $\mathrm{pH}$ or in concentrations of VFAs were noted. It can therefore be concluded that these factors were not responsible for changes in the community of microorganisms or the observed decrease in the yield of $\mathrm{CH}_{4}$ in most of the analysed digestate samples.

\subsection{Future Prospects}

This work concluded that antibiotics had the greatest impact on the AD process. The antimicrobials showed high toxicity to microorganisms, which directly reduced the production of biogas. To reduce antibiotic toxicity in digesters treating cattle manure co-fermentation is recommended, i.e., digesting the manure with the addition of, for example, cheese whey [72], which is locally available and easily biodegradable substrate. This method can significantly improve the stability of AD process range compared to the decomposition of a single substrate. The implementation of anaerobic digestion in full-size biogas plants located on large farms can be an environmentally friendly solution ensuring energy security for the farm, allowing for the reduction of transport and management costs. However, the condition for achieving these benefits is rational management of antibiotics and limiting their supply to animals.

\section{Conclusions}

The research has demonstrated the inhibitory effect of antibiotics on the efficiency of $\mathrm{AD}$ and $\mathrm{CH}_{4}$ production. The AD process in the presence of antibiotics also stimulates an increase in the number of ARGs and their spread in digestate samples. The antibiotics tested in this study were toxic not only to fermentation bacteria but also to methanogens, responsible for $\mathrm{CH}_{4}$ production. Antibiotics caused a change in the proportions of counts of bacteria relative to Archaea. In conclusion, it is necessary to monitor the AD process in biogas plants, the digestate obtained from this process and the environment to which such digestate is introduced. This work will enrich the database supporting the design and commissioning of the full-scale processes.

Supplementary Materials: The following are available online at https:/ / www.mdpi.com/1996-107 3/14/4/1125/s1, S1. Anaerobic digestion and Methane fermentation. S2. Analyses of antibiotics concentration. S3. Analyses of genes concentration. S4. Statistical analyses. Table S1: The characteristics of cattle manure used as substrate in AD process and anaerobic sludge used as inoculum. Table S2: The concentrations of antibiotics used in the investigations, per unit of reactor feed volume. Table S3: Primers sequences and parameters use for qPCR analysis. Table S4: The FOS/TAC ratio, concentration of nitrogen and phosphorus in biomass, and $\mathrm{pH}$ value in digestate samples from methane fermentation of cattle manure with the addition of selected antibiotics and in bioreactor with substrate without antibiotic supplementation (SA). Table S5: LC-MS/MS parameters for the investigated compounds. Table S6: Total compound concentration at the beginning of the experiment (C0) and in the equilibrium conditions (after the process) (Ct), per unit of reactor volume, $\mu \mathrm{g} \mathrm{L}^{-1}$. Table S7: Concentrations, sorption parameters and removal efficiency of the test substances during the anaerobic digestion. Table S8: Hydration of samples after the anaerobic digestion process. Table S9: Relative abundances (RAs) of genes specific for Archaea antibiotic resistance genes, and integrase 
genes in digestate with antibiotic addition and substrate without antibiotic addition. The relative abundances (RAs) of the ARGs were calculated as: copy number of ARG/copy number of $16 \mathrm{~S}$ rRNA. Figure S1: Average values ( \pm standard deviation) of methane production during anaerobic digestion in bioreactors with (A) MET, (B) AMO, (C) AMP, (D) ENR, (E) SMX, (F) OXY, (G) CHLOR, (H) TET supplementation, and (I) control reactor (SA). All the results presented are the means of two independent assays. Figure S2: Detailed taxonomy and community structure of Archaea and bacteria (based on the OTUs) up to species in digestate with supplementation of selected antibiotics and in bioreactor with substrate without antibiotic supplementation (SA). Figure S3: Frame-mustache charts showing the results of the Kruskal-Wallis test (ANOVA). Statistically significant changes in the concentration of genes specific for Archaea like (a) mcrA gene, (b) MSC gene, (c) MST gene are marked with an asterisk $\left(^{*}\right)$ ( $p$-values $<0.05$ were considered statistically significant). Figure S4: Framemustache charts showing the results of the Kruskal-Wallis test (ANOVA). Statistically significant changes in the concentration of tet genes like (a) tet A, (b) tet $\mathrm{M},(\mathrm{c})$ tet $\mathrm{Q}$, are marked with an asterisk (*) ( $p$-values $<0.05$ were considered statistically significant). Figure S5: Frame-mustache charts showing the results of the Kruskal-Wallis test (ANOVA). Statistically significant changes in the concentration of bla genes like (a) blaTEM, (b) blaOXA, (c) cfxA, are marked with an asterisk $\left(^{*}\right)$ ( $p$-values $<0.05$ were considered statistically significant). Figure S6: Frame-mustache charts showing the results of the Kruskal-Wallis test (ANOVA). Statistically significant changes in the concentration of sul1 genes are marked with an asterisk $\left(^{*}\right)$ ( $p$-values $<0.05$ were considered statistically significant). Figure S7: Frame-mustache charts showing the results of the Kruskal-Wallis test (ANOVA). Statistically significant changes in the concentration of MLS group genes like (a) $\operatorname{erm} \mathrm{F}$, (b) $\operatorname{lin} \mathrm{A}$, (c) mef A, are marked with an asterisk $\left.{ }^{*}\right)$ ( $p$-values $<0.05$ were considered statistically significant). Figure S8: Frame-mustache charts showing the results of the Kruskal-Wallis test (ANOVA). Statistically significant changes in the concentration of fluoroquinolones genes like (a) qep $\mathrm{A}$, (b) aac- $\left(6^{\prime}\right)-I b-c r$ are marked with an asterisk $\left(^{*}\right)$ ( $p$-values $<0.05$ were considered statistically significant). Figure S9: Frame-mustache charts showing the results of the Kruskal-Wallis test (ANOVA). Statistically significant changes in the concentration of integrase genes like (a) intI1, (b) intI2 are marked with an asterisk $\left({ }^{*}\right)(p$-values $<0.05$ were considered statistically significant). References [73-84] are cited in the Supplementary Materials.

Author Contributions: Conceptualization, I.K. and M.H.; formal analysis, S.B., E.F. and P.R.; funding acquisition, M.H.; investigation, I.K.; methodology, M.H., S.B., E.F. and P.R.; resources, M.H.; software, J.P.J. and Ł.P.; supervision, M.H. and E.K.; visualization, I.K., J.P.J. and Ł.P; writing-original draft, I.K., M.C., S.B., E.F. and P.R.; writing-review and editing, M.H. and E.K. All authors have read and agreed to the published version of the manuscript.

Funding: This work was financially supported by Grant No. 2016/23/B/NZ9/03669 from the National Science Centre (Poland). The project was financially co-supported by the Minister of Science and Higher Education in the range of the program entitled "Regional Initiative of Excellence" for the years 2019-2022, Project No. 010/RID/2018/19, amount of funding 12.000.000 PLN.

Institutional Review Board Statement: Not applicable.

Informed Consent Statement: Not applicable.

Data Availability Statement: Data sharing not applicable.

Acknowledgments: The authors would like to thank Marcin Dębowski and Marcin Zieliński for their help and the support.

Conflicts of Interest: The authors declare no conflict of interest.

\section{References}

1. Adekunle, K.F.; Okolie, J.A. A Review of Biochemical Process of Anaerobic Digestion. Adv. Biosci. Biotechnol. 2015, 6, 205-212. [CrossRef]

2. Spielmeyer, A. Occurrence and fate of antibiotics in manure during manure treatments: A short review. Sustain. Chem. Pharm. 2018, 9, 76-86. [CrossRef]

3. Wallace, J.S.; Aga, D.S. Enhancing Extraction and Detection of Veterinary Antibiotics in Solid and Liquid Fractions of Manure. J. Environ. Qual. 2016, 45, 471-479. [CrossRef]

4. Ahmad, M.; Vithanage, M.; Kim, K.; Cho, J.-S.; Lee, Y.H.; Joo, Y.K.; Lee, S.S.; Ok, Y.S. Inhibitory Effect of Veterinary Antibiotics on Denitrification in Groundwater: A Microcosm Approach. Sci. World J. 2014, 2014, 1-7. [CrossRef] [PubMed] 
5. Gou, M.; Hu, H.-W.; Zhang, Y.-J.; Wang, J.-T.; Hayden, H.; Tang, Y.-Q.; He, J.-Z. Aerobic composting reduces antibiotic resistance genes in cattle manure and the resistome dissemination in agricultural soils. Sci. Total. Environ. 2018, 612, 1300-1310. [CrossRef]

6. Zhang, Q.; Wang, M.; Ma, X.; Gao, Q.; Wang, T.; Shi, X.; Zhou, J.; Zuo, J.; Yang, Y. High variations of methanogenic microorganisms drive full-scale anaerobic digestion process. Environ. Int. 2019, 126, 543-551. [CrossRef]

7. Tian, Z.; Zhang, Y.; Yu, Z.; Yang, M. Changes of resistome, mobilome and potential hosts of antibiotic resistance genes during the transformation of anaerobic digestion from mesophilic to thermophilic. Water Res. 2016, 98, 261-269. [CrossRef] [PubMed]

8. Klein, E.Y.; Van Boeckel, T.P.; Martinez, E.M.; Pant, S.; Gandra, S.; Levin, S.A.; Goossens, H.; Laxminarayan, R. Global increase and geographic convergence in antibiotic consumption between 2000 and 2015. Proc. Natl. Acad. Sci. USA 2018, 115, E3463-E3470. [CrossRef]

9. Arikan, O.A.; Sikora, L.J.; Mulbry, W.; Khan, S.U.; Rice, C.; Foster, G.D. The fate and effect of oxytetracycline during the anaerobic digestion of manure from therapeutically treated calves. Process. Biochem. 2006, 41, 1637-1643. [CrossRef]

10. Lallai, A.; Mura, G.; Onnis, N. The efects of certain antibiotics on biogas production in the naerobic di-gestion. Bioresour. Technol. 2002, 82, 205-208. [CrossRef]

11. Loftin, K.A.; Henny, C.; Adams, C.D.; Surampali, R.; Mormile, M.R. Inhibition of microbial metabolism in anaerobic lagoons by selected sulfonamides, tetracyclines, lincomycin, and tylosin tartrate. Environ. Toxicol. Chem. 2005, 24, 782-788. [CrossRef] [PubMed]

12. Chambers, L.; Yang, Y.; Littier, H.; Ray, P.; Zhang, T.; Pruden, A.; Strickland, M.; Knowlton, K. Metagenomic Analysis of Antibiotic Resistance Genes in Dairy Cow Feces following Therapeutic Administration of Third Generation Cephalosporin. PLoS ONE 2015, 10, e0133764. [CrossRef] [PubMed]

13. Han, X.-M.; Hu, H.-W.; Chen, Q.-L.; Yang, L.-Y.; Li, H.-L.; Zhu, Y.-G.; Li, X.-Z.; Ma, Y.-B. Antibiotic resistance genes and associated bacterial communities in agricultural soils amended with different sources of animal manures. Soil Biol. Biochem. 2018, 126, 91-102. [CrossRef]

14. Song, W.; Wang, X.; Gu, J.; Zhang, S.; Yin, Y.; Li, Y.; Qian, X.; Sun, W. Effects of different swine manure to wheat straw ratios on antibiotic resistance genes and the microbial community structure during anaerobic digestion. Bioresour. Technol. 2017, 231, 1-8. [CrossRef] [PubMed]

15. Wang, S.; Du, K.; Yuan, R.; Chen, H.; Wang, F.; Zhou, B. Effects of sulfonamide antibiotics on digestion performance and microbial community during swine manure anaerobic digestion. Environ. Eng. Res. 2020, 26, 1. [CrossRef]

16. Wang, Q.; Li, X.; Yang, Q.; Chen, Y.; Du, B. Evolution of microbial community and drug resistance during enrichment of tetracycline-degrading bacteria. Ecotoxicol. Environ. Saf. 2019, 171, 746-752. [CrossRef]

17. Bajkacz, S.; Felis, E.; Kycia-Słocka, E.; Harnisz, M.; Korzeniewska, E. Development of a new SLE-SPE-HPLC-MS/MS method for the determination of selected antibiotics and their transformation products in anthropogenically altered solid environmental matrices. Sci. Total. Environ. 2020, 726, 138071. [CrossRef]

18. Klindworth, A.; Pruesse, E.; Schweer, T.; Peplies, J.; Quast, C.; Horn, M.; Glöckner, F.O. Evaluation of general 16S ribosomal RNA gene PCR primers for classical and next-generation sequencing-based diversity studies. Nucleic Acids Res. 2013, 41, e1. [CrossRef]

19. Kohanski, M.A.; Dwyer, D.J.; Collins, J.J. How antibiotics kill bacteria: From targets to networks. Nat. Rev. Genet. 2010, 8, 423-435. [CrossRef]

20. Czatzkowska, M.; Harnisz, M.; Korzeniewska, E.; Koniuszewska, I. Inhibitors of the methane fermentation process with particular emphasis on the microbiological aspect: A review. Energy Sci. Eng. 2020, 8, 1880-1897. [CrossRef]

21. Wang, F.; Han, W.; Chen, S.; Dong, W.; Qiao, M.; Hu, C.; Liu, B. Fifteen-Year Application of Manure and Chemical Fertilizers Differently Impacts Soil ARGs and Microbial Community Structure. Front. Microbiol. 2020, 11, 62. [CrossRef]

22. Aydin, S.; Cetecioglu, Z.; Arikan, O.; Ince, B.; Ozbayram, E.G.; Ince, O. Inhibitory effects of antibiotic combinations on syntrophic bacteria, homoacetogens and methanogens. Chemosphere 2015, 120, 515-520. [CrossRef]

23. Morris, R. Relating Methanogen Community Structure to Function in Anaerobic Wastewater Digesters. Diss. 2009. Available online: http:/ / epublications.marquette.edu/dissertations_mu/138 (accessed on 20 October 2020).

24. Ghosh, P.; Kumar, M.; Kapoor, R.; Kumar, S.S.; Singh, L.; Vijay, V.; Vijay, V.K.; Kumar, V.; Thakur, I.S. Enhanced biogas production from municipal solid waste via co-digestion with sewage sludge and metabolic pathway analysis. Bioresour. Technol. 2020, 296, 122275. [CrossRef] [PubMed]

25. Bauer, A.; Lizasoain, J.; Nettmann, E.; Bergmann, I.; Mundt, K.; Klocke, M.; Rincon, M.; Amon, T.; Piringer, G. Effects of the Antibiotics Chlortetracycline and Enrofloxacin on the Anaerobic Digestion in Continuous Experiments. BioEnergy Res. 2014, 7 , 1244-1252. [CrossRef]

26. Sun, J.P.; Zheng, P.; Hu, B.L. Combined effect of antibiotics on anaerobic digestion of piggery wastewater. Huan Jing Ke Xue 2009, 30, 19-24.

27. Nuengjamnong, C.; Rachdawong, P.; Chalermchaikit, T. Effect of amoxicillin on biogas production and the Eschericia coli population in biogas systems treating swine wastewater. Thai J. Vet. Med. 2010, 40, 57-62.

28. Qiao, M.; Ying, G.-G.; Singer, A.C.; Zhu, Y.-G. Review of antibiotic resistance in China and its environment. Environ. Int. 2018, 110, 160-172. [CrossRef]

29. Massé, D.; Lu, D.; Masse, L.; Droste, R. Effect of antibiotics on psychrophilic anaerobic digestion of swine manure slurry in sequencing batch reactors. Bioresour. Technol. 2000, 75, 205-211. [CrossRef] 
30. Álvarez, J.; Otero, L.; Lema, J.; Omil, F. The effect and fate of antibiotics during the anaerobic digestion of pig manure. Bioresour. Technol. 2010, 101, 8581-8586. [CrossRef]

31. Loke, M.L.; Jespersen, S.; Vreeken, R.; Halling-Sørensen, B.; Tjørnelund, J. Determination of oxytetracycline and its degradation products by high-performance liquid chromatography-tandem mass spectrometry in manure-containing anaerobic test systems. J. Chromatogr. B 2003, 783, 11-23. [CrossRef]

32. Kuhne, M.; Ihnen, D.; Moller, G.; Agthe, O. Stability of tetracycline in water and liquid manure. J. Vet. Med. Ser. A 2000, 47, 379-384. [CrossRef] [PubMed]

33. Arikan, O.A. Degradation and metabolization of chlortetracycline during the anaerobic digestion of manure from medicated calves. J. Hazard. Mater. 2008, 158, 485-490. [CrossRef]

34. Arsand, J.B.; Hoff, R.B.; Jank, L.; Meirelles, L.N.; Díaz-Cruz, M.S.; Pizzolato, T.M.; Barceló, D. Transformation products of amoxicillin and ampicillin after photolysis in aqueous matrices: Identification and kinetics. Sci. Total. Environ. 2018, 642, 954-967. [CrossRef] [PubMed]

35. Keßler, D.N.; Fokuhl, V.K.; Petri, M.S.; Spielmeyer, A. Abiotic transformation products of tetracycline and chlortetracycline in salt solutions and manure. Chemosphere 2019, 224, 487-493. [CrossRef] [PubMed]

36. Zhou, L.; Gao, Y.; Yu, K.; Zhou, H.; De Costa, Y.G.; Yi, S.; Zhuang, W.-Q. Microbial community in in-situ waste sludge anaerobic digestion with alkalization for enhancement of nutrient recovery and energy generation. Bioresour. Technol. 2020, $295,122277$. [CrossRef] [PubMed]

37. De Vrieze, J.; Hennebel, T.; Brande, J.V.D.; Bilad, R.M.; Bruton, T.A.; Vankelecom, I.F.; Verstraete, W.; Boon, N. Anaerobic digestion of molasses by means of a vibrating and non-vibrating submerged anaerobic membrane bioreactor. Biomass Bioenergy 2014, 68, 95-105. [CrossRef]

38. Ning, J.; Zhou, M.; Pan, X.; Li, C.; Lv, N.; Wang, T.; Cai, G.; Wang, R.; Li, J.; Zhu, G. Simultaneous biogas and biogas slurry production from co-digestion of pig manure and corn straw: Performance optimization and microbial community shift. Bioresour. Technol. 2019, 282, 37-47. [CrossRef]

39. De Vrieze, J.; Saunders, A.M.; He, Y.; Fang, J.; Nielsen, P.H.; Verstraete, W.; Boon, N. Ammonia and temperature determine potential clustering in the anaerobic digestion microbiome. Water Res. 2015, 75, 312-323. [CrossRef]

40. Zhang, Y.-J.; Hu, H.-W.; Chen, Q.-L.; Singh, B.K.; Yan, H.; Chen, D.; He, J.-Z. Transfer of antibiotic resistance from manure-amended soils to vegetable microbiomes. Environ. Int. 2019, 130, 104912. [CrossRef] [PubMed]

41. Qian, X.; Sun, W.; Gu, J.; Wang, X.-J.; Sun, J.-J.; Yin, Y.-N.; Duan, M.-L. Variable effects of oxytetracycline on antibiotic resistance gene abundance and the bacterial community during aerobic composting of cow manure. J. Hazard. Mater. 2016, 315, 61-69. [CrossRef]

42. Levén, L.; Eriksson, A.R.B.; Schnürer, A. Effect of process temperature on bacterial and archaeal communities in two methanogenic bioreactors treating organic household waste. FEMS Microbiol. Ecol. 2007, 59, 683-693. [CrossRef] [PubMed]

43. Limam, R.D.; Chouari, R.; Mazéas, L.; Wu, T.; Li, T.; Grossin-Debattista, J.; Guerquin-Kern, J.; Saidi, M.; Landoulsi, A.; Sghir, A.; et al. Members of the uncultured bacterial candidate division WWE 1 are implicated in anaerobic digestion of cellulose. MicrobiologyOpen 2014, 3, 157-167. [CrossRef]

44. Delbès, C. Bacterial and archaeal 16S rDNA and 16S rRNA dynamics during an acetate crisis in an anaerobic digestor ecosystem. FEMS Microbiol. Ecol. 2001, 35, 19-26. [CrossRef]

45. Morris, R.; Schauer-Gimenez, A.; Bhattad, U.; Kearney, C.; Struble, C.A.; Zitomer, D.; Maki, J.S. Methyl coenzyme M reductase (mcrA) gene abundance correlates with activity measurements of methanogenic H 2 / CO 2 -enriched anaerobic biomass. Microb. Biotechnol. 2014, 7, 77-84. [CrossRef]

46. Aydin, S.; Ince, B.; Ince, O. Application of real-time PCR to determination of combined effect of antibiotics on Bacteria, Methanogenic Archaea, Archaea in anaerobic sequencing batch reactors. Water Res. 2015, 76, 88-98. [CrossRef]

47. Cetecioglu, Z.; Ince, B.; Gros, M.; Rodriguez-Mozaz, S.; Barceló, D.; Orhon, D.; Ince, O. Chronic impact of tetracycline on the biodegradation of an organic substrate mixture under anaerobic conditions. Water Res. 2013, 47, 2959-2969. [CrossRef]

48. Martinez, J.L. Environmental pollution by antibiotics and by antibiotic resistance determinants. Environ. Pollut. 2009, 157, 2893-2902. [CrossRef]

49. Wu, X.; Wei, Y.; Zheng, J.; Zhao, X.; Zhong, W. The behavior of tetracyclines and their degradation products during swine manure composting. Bioresour. Technol. 2011, 102, 5924-5931. [CrossRef]

50. Wang, L.; Wang, J.; Wang, J.; Zhu, L.; Yang, L.; Yang, R. Distribution characteristics of antibiotic resistant bacteria and genes in fresh and composted manures of livestock farms. Sci. Total Environ. 2019, 695, 133781. [CrossRef] [PubMed]

51. Speece, R.E. Anaerobic biotechnology for industrial wastewater treatment a description of several installations. Environ. Sci. Technol. 1983, 17, 416-427. [CrossRef]

52. Bauer, F.; Perrson, T.; Hulteberg, C.; Tamm, D. Perspective: Jatropha cultivation in southern India: Assessing farmers' experiences Biofuels Bioprod. Biorefining 2014, 7, 499-511. [CrossRef]

53. Turker, G.; Ince, O.; Ertekin, E.; Akyol, C.; Ince, B. Changes in performance and active microbial communities due to single and multiple effects of mixing and solid content in anaerobic digestion process of otc medicated cattle manure. Int. J. Renew. Energy Res. 2013, 3, 144-148. [CrossRef]

54. Santamaría, J.; López, L.; Soto, C.Y. Detection and diversity evaluation of tetracycline resistance genes in grassland-based production systems in Colombia, South America. Front. Microbiol. 2011, 2, 252. [CrossRef] [PubMed] 
55. Selvam, A.; Xu, D.; Zhao, Z.; Wong, J.W. Fate of tetracycline, sulfonamide and fluoroquinolone resistance genes and the changes in bacterial diversity during composting of swine manure. Bioresour. Technol. 2012, 126, 383-390. [CrossRef] [PubMed]

56. Baker-Austin, C.; Wright, M.S.; Stepanauskas, R.; McArthur, J. Co-selection of antibiotic and metal resistance. Trends Microbiol. 2006, 14, 176-182. [CrossRef] [PubMed]

57. Allen, H.K.; Looft, T.; Bayles, D.O.; Humphrey, S.; Levine, U.Y.; Alt, D.; Stanton, T.B. Antibiotics in Feed Induce Prophages in Swine Fecal Microbiomes. MBio 2011, 2, 1-9. [CrossRef] [PubMed]

58. Mroczkowska, J.E.; Barlow, M. Fitness Trade-Offs in blaTEM Evolution. Antimicrob. Agents Chemother. 2008, 52, 2340-2345. [CrossRef]

59. Myllyniemi, A.-L.; Rannikko, R.; Lindfors, E.; Niemi, A.; Bäckman, C. Microbiological and chemical detection of incurred penicillin G, oxytetracycline, enrofloxacin and ciprofloxacin residues in bovine and porcine tissues. Food Addit. Contam. 2000, 17, 991-1000. [CrossRef]

60. Miryala, S.K.; Anbarasu, A.; Ramaiah, S. Role of SHV-11, a Class A $\beta$-Lactamase, Gene in Multidrug Resistance among Klebsiella pneumoniae Strains and Understanding Its Mechanism by Gene Network Analysis. Microb. Drug Resist. 2020, 26, 900-908. [CrossRef] [PubMed]

61. Oliver, J.P.; Gooch, C.A.; Lansing, S.; Schueler, J.; Hurst, J.J.; Sassoubre, L.; Crossette, E.M.; Aga, D.S. Invited review: Fate of antibiotic residues, antibiotic-resistant bacteria, and antibiotic resistance genes in US dairy manure management systems. J. Dairy Sci. 2020, 103, 1051-1071. [CrossRef]

62. Xie, S.; Wickham, R.; Nghiem, L.D. Synergistic effect from anaerobic co-digestion of sewage sludge and organic wastes. Int. Biodeterior. Biodegrad. 2017, 116, 191-197. [CrossRef]

63. Bouanane-Darenfed, A.; Fardeau, M.-L.; Grégoire, P.; Joseph, M.; Kebbouche-Gana, S.; Benayad, T.; Hacène, H.; Cayol, J.-L.; Ollivier, B. Caldicoprobacter algeriensis sp. nov. a New Thermophilic Anaerobic, Xylanolytic Bacterium Isolated from an Algerian Hot Spring. Curr. Microbiol. 2010, 62, 826-832. [CrossRef]

64. Nowara, A.; Burhenne, A.J.; Spiteller, M. Binding of Fluoroquinolone Carboxylic Acid Derivatives to Clay Minerals. J. Agric. Food Chem. 1997, 45, 1459-1463. [CrossRef]

65. Qu, A.; Brulc, J.M.; Wilson, M.K.; Law, B.F.; Theoret, J.R.; Joens, L.A.; Konkel, M.E.; Angly, F.; Dinsdale, E.A.; Edwards, R.A.; et al. Comparative Metagenomics Reveals Host Specific Metavirulomes and Horizontal Gene Transfer Elements in the Chicken Cecum Microbiome. PLoS ONE 2008, 3, e2945. [CrossRef] [PubMed]

66. Gaze, W.H.; Zhang, L.; Abdouslam, N.A.; Hawkey, P.M.; Calvo-Bado, L.A.; Royle, J.; Brown, H.; Davis, S.D.; Kay, P.; Boxall, A.B.A.; et al. Impacts of anthropogenic activity on the ecology of class 1 integrons and integron-associated genes in the environment. ISME J. 2011, 5, 1253-1261. [CrossRef]

67. Nesme, J.; Simonet, P. The soil resistome: A critical review on antibiotic resistance origins, ecology and dissemination potential in telluric bacteria. Environ. Microbiol. 2015, 17, 913-930. [CrossRef] [PubMed]

68. Zhu, Y.; Yi, Y.; Liu, F.; Lv, N.; Yang, X.; Li, J.; Hu, Y.; Zhu, B. Distribution and molecular profiling of class 1 integrons in MDR Acinetobacter baumannii isolates and whole genome-based analysis of antibiotic resistance mechanisms in a representative strain. Microbiol. Res. 2014, 169, 811-816. [CrossRef]

69. Luo, Y.; Mao, D.; Rysz, M.; Zhou, Q.; Zhang, H.; Xu, L.; Alvarez, P.J.J. Trends in Antibiotic Resistance Genes Occurrence in the Haihe River, China. Environ. Sci. Technol. 2010, 44, 7220-7225. [CrossRef]

70. Gao, P.; Gu, C.; Wei, X.; Li, X.; Chen, H.; Jia, H.; Liu, Z.; Xue, G.; Ma, C. The role of zero valent iron on the fate of tetracycline resistance genes and class 1 integrons during thermophilic anaerobic co-digestion of waste sludge and kitchen waste. Water Res. 2017, 111, 92-99. [CrossRef]

71. Zhang, X.; Gu, J.; Wang, X.; Zhang, K.; Yin, Y.; Zhang, R.; Zhang, S. Effects of tylosin, ciprofloxacin, and sulfadimidine on mcrA gene abundance and the methanogen community during anaerobic digestion of cattle manure. Chemosphere 2019, 221, 81-88. [CrossRef] [PubMed]

72. Mainardis, M.; Flaibani, S.; Trigatti, M.; Goi, D. Techno-economic feasibility of anaerobic digestion of cheese whey in small Italian dairies and effect of ultrasound pre-treatment on methane yield. J. Environ. Manag. 2019, 246, 557-563. [CrossRef] [PubMed]

73. Ternes, T.; Joss, A. Pharmaceuticals and personal care products in Wastewater Treatment. Environ. Sci. Technol. 2004, 10, 393-399.

74. Bolger, A.M.; Lohse, M.; Usadel, B. Trimmomatic: A flexible trimmer for Illumina sequence data. Bioinformatics 2014, 30, 2114-2120. [CrossRef] [PubMed]

75. Callahan, B.J.; McMurdie, P.J.; Rosen, M.J.; Han, A.W.; Johnson, A.J.A.; Holmes, S.P. DADA2: High-resolution sample inference from Illumina amplicon data. Nat. Methods 2016, 13, 581-583. [CrossRef]

76. Kim, J.; Jeon, S.; Rhie, H.; Lee, B.; Park, M.; Lee, H.; Lee, J.; Kim, S. Rapid Detection of Extended Spectrum $\beta$-Lactamase (ESBL) for Enterobacteriaceae by use of a Multiplex PCR-based Method. Infect. Chemother. 2009, 41, 181. [CrossRef]

77. Eitel, Z.; Sóki, J.; Urbán, E.; Nagy, E. The prevalence of antibiotic resistance genes in Bacteroides fragilis group strains isolated in different European countries. Anaerobe 2013, 21, 43-49. [CrossRef] [PubMed]

78. Li, J.; Wang, T.; Shao, B.; Shen, J.; Wang, S.; Wu, Y. Plasmid-mediated quinolone resistance genes and antibiotic residues in wastewater and soil adjacent to swine feedlots: Potential transfer to agricultural lands. Environ. Health Perspect. 2012, 120, 1144-1149. [CrossRef] [PubMed]

79. Park, C.H.; Robicsek, A.; Jacoby, G.A.; Sahm, D.; Hooper, D.C. Prevalence in the United States of aac $\left(6^{\prime}\right)$-Ib-cr encoding a ciprofloxacin-modifying enzyme. Antimicrob. Agents Chemother. 2006, 50, 3953-3955. [CrossRef] 
80. Nawaz, M.; Sung, K.; Khan, S.A.; Khan, A.A.; Steele, R. Biochemical and molecular characterization of tetracycline-resistant Aeromonas veronii isolates from catfish. Appl. Environ. Microbiol. 2006, 72, 6461-6466. [CrossRef]

81. Ng, L.K.; Martin, I.; Alfa, M.; Mulvey, M. Multiplex PCR for the detection of tetracycline resistant genes. Mol. Cell. Probes 2001, 15, 209-215. [CrossRef]

82. Nadkarni, M.A.; Martin, F.E.; Jacques, N.A.; Hunter, N. Determination of bacterial load by real-time PCR using a broad-range (universal) probe and primers set. Microbiology 2002, 148, 257-266. [CrossRef] [PubMed]

83. Goldstein, C.; Lee, M.D.; Sanchez, S.; Hudson, C.; Phillips, B.; Register, B.; Grady, M.; Liebert, C.; Summers, A.O.; White, D.G.; et al. Incidence of class 1 and 2 integrases in clinical and commensal bacteria from livestock, companion animals, and exotics. Antimicrob. Agents Chemother. 2001, 45, 723-726. [CrossRef] [PubMed]

84. Luton, P.E.; Wayne, J.M.; Sharp, R.J.; Riley, P.W. The mcrA gene as an alternative to $16 \mathrm{~S}$ rRNA in the phylogenetic analysis of methanogen populations in landfill. Microbiology 2002, 148, 3521-3530. [CrossRef] [PubMed] 